\title{
SINGLE UNIT DISCRIMINATION OF FISH ODOURS RELEASED BY CHAR (SALMO ALPINUS L.) POPULATIONS*
}

\author{
KJELL B. DØVING ${ }^{1}$, HANS NORDENG ${ }^{2}$ and BRUCE OAKLEY ${ }^{3}$ \\ ${ }^{1}$ Institute of Zoophysiology and '2oological Laboratory, University of Oslo, \\ Blindern, Oslo 3, Norway; and 'Department of Zoology, University of Michigan, \\ Ann Arbor, Michigan 48104, U.S.A.
}

(Received 26 April 1973)

\begin{abstract}
Dilute fish odours from four distinct char populations elicited differential responses from char olfactory bulb cells.

2. Differential sensory responses produced by odours from migratory and non-migratory populations of char suggest that fish odours could act as pheromones which help guide homing in these salmonids.

3. Skin mucous may well be the principal source of odorants released by the char.
\end{abstract}

\section{INTRODUCTION}

EXTENSIVE tagging experiments have shown that migratory salmonids return to their fresh-water birthplaces to spawn (e.g. Clements et al., 1939; for reviews see Harden Jones, 1968; Stasko, 1971). Not only must the olfactory system be intact and functioning for such accurate near-orientation to the spawning grounds (e.g. Wisby \& Hasler, 1954; Groves et al., 1968), but it also must be remarkably discriminating inasmuch as migratory salmonids may bypass and travcrse numcrous strcams and lakes before their migration ceases in their own home areas.

Authorities on salmon migration have hypothesized that the odorants which guide homing emanate from the plants and minerals characteristic of the home stream waters (Hasler, 1960,1970). The possibility of fish pheromones has not been adequately considered, even though various behavioral experiments suggest species and perhaps individual recognition based on odour. For example, Wrede (1932) demonstrated that minnows (Phoxinus phoxinus (L.)) were attracted to and recognized other members of their species on the basis of odorants in skin mucous. The results obtained by Wrede were confirmed and extended on minnows by Göz (1941) and on yellow bullhead (Ictalurus natalis) by Todd et al. (1967). Alarm substances are also well known in fishes (von Frisch, 1941; Pfeiffer, 1962). Recently Nordeng (1971) has shown that anadromous char from northern Norway (Salangen), which were reared for 3 years in southern Norway (Voss), went back to their

* This work was supported in part by the Norwegian Research Council for Science and the Humanities and by U.S. Public Health Service Grant No. NS-07072 to B. O. 
parent's river when released in the Salangen fjord (Fig. 1). He suggests that young char resident in the spawning area of the home river release a pheromone in their mucous which attracts the migrating fish. Electrophysiological experiments by Døving $e t$ al. (1973) have shown that fish mucous is an effective olfactory stimulus and could be a source of such pheromones. Consequently, we wished to make an initial electrophysiological examination of the capacity of char to detect and

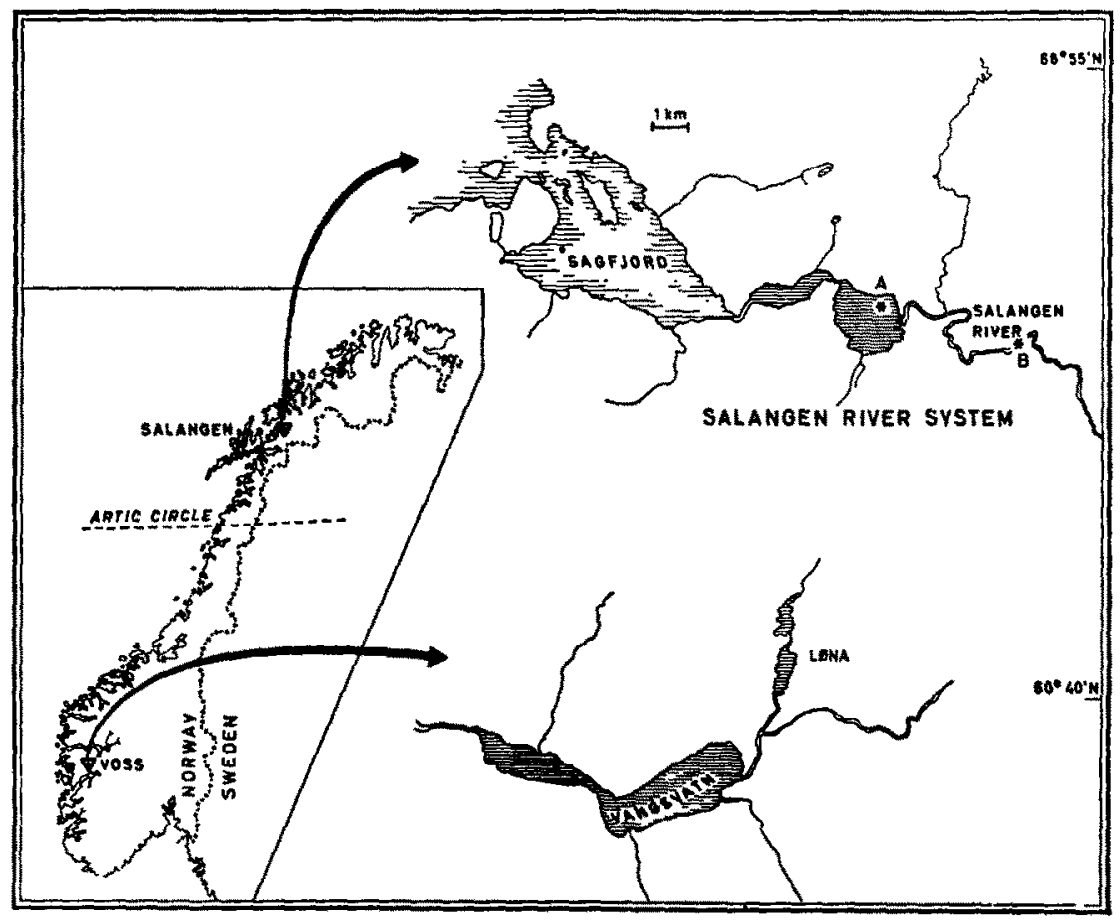

Fig. 1. Map showing the locations of char populations used for the present study. Lake Vangsvatn and Lake Lona indicated at Voss. The asterisks marked A and B indicate the spawning sites of the stationary and migratory Salangen char respectively.

distinguish among appropriate fish odours. The only attempts, thus far, to study the electrophysiological correlates of homing in salmonids have relied upon EEG responses of the olfactory bulb. These initial studies concluded that for spawning salmon, home water, among the several natural waters tested, was the only effective stimulant for EEG arousal (Hara et al, 1965) or at least it was the most effective stimulant (Ueda et al., 1967). This work has been criticized by Oshima et al. $(1969 \mathrm{~b})$ because of the deteriorated condition of the fish and the lack of fresh samples of the waters used for stimulation. With healthy fish and new water samples they found that all natural waters tested were effective stimulants of the EEG; sometimes as effective as home water. In further tests it was determined 
that there was no systematic increase in EEG arousal to samples of water obtained along the migratory route (Oshima et al., 1969c). It was expected that the set of odours emanating from and specific to the home stream would increase in concentration along the migratory route. However, this is not likely to be evident from a gross EEG response because it is aroused by all effective odorants that are present along the migratory route. It is clear that a more discriminating electrophysiological measure would be helpful in experiments on salmonid homing.

In the present experiment we wanted to examine the possibility that various geographic populations of char release characteristic odours that elicit differential responses in the char olfactory system. Thus, it was necessary to show: (a) that the receptors could detect the odours and (b) that olfactory response differed qualitatively depending upon the char populations used. The results support the assumption that char can discriminate among odours of different char populations.

\section{MATERIALS AND METHODS}

In Norway, the populations of char (Salmo alpinus L. = Salvelinus alpinus (L.)) have not been involved in fish cultivation, and thus each river system has its own original populations. In southern Norway all char populations are stationary, staying in fresh water during their whole life span. North of $65^{\circ} \mathrm{N}$, just south of the Arctic circle, stationary and migratory populations occur together in most of the water systems. In the Salangen water system (Fig. 1) individuals of the migratory population in the post-smolt stage migrate to the sea once a year for up to 10 years. Even though this population is mixed in the sea with other migratory populations, they separate annually and return to individual nursery areas in their native river system (Nordeng, 1971).

Our fish came from the stationary and the migratory populations in the Salangen river system and from two stationary populations in the Voss river system, about $1100 \mathrm{~km}$ further south (Fig. 1). One of the Voss populations inhabits Lake Vangsvatn in the middle of the river system, and the other Lake Lana in the upper part of the system. The Lana population have been reproductively isolated from the Vangsvatn population by a waterfall for at least 5000 years. Adult Salangen stationary and migratory char may be classified by scale structures and external characters, while the young char in the river system are found to form a uniform group (Nordeng, 1961, p. 72).

We used as odorant sources young char originating from the two Salangen and the two Voss populations mentioned above. They were reared separately for 2 years before being used in our experiments. In addition, we used adult char of Løna and Vangsvatn caught with beach seine in June 1972.

These six experimental groups of fish were maintained in 120-1. tanks (one for each size and type) with $9^{\circ} \mathrm{C}$ water continuously supplied from large holding receptacles that contained the lake water supplying the city of Oslo. Each tank contained about twenty fish $(15-20 \mathrm{~cm})$. The recording was done from adult Vangsvatn char $(29-34 \mathrm{~cm})$. In addition, one recording was made from an immature migratory char $(29 \mathrm{~cm})$, caught on its upstream run, and one recording from a young Salangen stationary char, reared at Voss. The experiments were performed in July and August 1972.

\section{Operative procedures and recording}

The fish were anesthetized with MS 222 (Sandoz) and paralyzed with $d$-tubocurarine. It was wrapped in a wet sponge and secured in a Plexiglass form by a head-holder and by steel rods for the body. The fish was perfused through the mouth with $9^{\circ} \mathrm{C}$ aquarium water with temperature automatically monitored every $30 \mathrm{~min}$. Water was also gently applied 
along the dorsal surface of the fish. The EKG was continuously monitored. The olfactory bulbs were exposed and photographed prior to recording. $\mathrm{KCl}(3 \mathrm{M})$ glass micropipettes were used to penetrate into the bulb and record action potentials extracellularly. A continuous flow of rinse solution (outflow from tank with no fish) was used during the search for a single unit. With rare exception units thus isolated were spontaneously active, although since the aquarium water was derived from local lake water with its own fish population including some char, the rinse itself may well have been stimulating. No attempt was made to use distilled water routinely, either as tank or as a rinse solution, because of possible damage to the olfactory mucosa by such continued exposure to distilled water. The action potentials were recorded by d.c. preamplification and displayed on a 565 Tektronix oscilloscope. In addition, the spikes/sec were counted (Hewlet-Packard Digital Counter) and an on-line printout (Systron-Donner Digital Printer H5103) obtained. A Tandberg Series 100 d.c. tape recorder was used to record the: (a) voice protocol record of the stimulation procedure, (b) stimulus marker, (c) EKG or stimulus temperature and (d) spike record. After isolation of a single unit and preliminary testing, two or three stimulation trials were carried out. The rinse solution was applied twice as long as necessary to bring the activity to its pre-stimulus level; typically $15-20 \mathrm{sec}$.

The stimuli most commonly employed were tank waters from each of the six groups of char. No attempt was made to store the tank waters; they were always obtained fresh for each experiment. Use of water entering or leaving a tank without fish served to control for stimulation either by mechanical or thermal means or by plastic or other contaminants of the aquarium water system. As an additional control for thermal stimulation a thermocouple was used to monitor temperature in many of the experiments. About $10 \mathrm{~cm}^{3}$ of the stimulus was applied at $0.5 \mathrm{ml} / \mathrm{sec}$ to the olfactory epithelium by a funnel whose spout was directed to the anterior nasal opening.

In most experiments the rinse solution was water taken from the exit of a tank without fish. In some experiments the rinse solution was a 1:1 mixture of water from a tank without fish and water from the tank with adult Vangsvatn char. In these cases the test stimuli were a 1:1 mixture of adult Vangsvatn tank water and water from the tank containing another group of char. This latter situation may more closely approximate the natural discrimination conditions confronted by char.

The flow of water through the tanks was $2 \cdot 4-61 . / \mathrm{min}$ or $2-5$ per cent of the watervolume per min. This means that the stimulatory chemicals liberated by the fish, of which slime is a major component, were quite dilute and were not cumulating in stagnant conditions. It is important to emphasize at this time that these tanks were not fouled with food, algae or suspended particles. The continuous supply of fresh water prevented stagnant accumulation of fish byproducts.

\section{RESULTS}

Recordings of nervous activity from single cells were made from right and left olfactory bulbs. The penetrations were made in the middle region of the bulb between 0.3 and $0.9 \mathrm{~mm}$ from the midline and $0.3-1.1 \mathrm{~mm}$ anterior to the border of the telencephalon (Fig. 2). Single unit activity was found at all depths down to $1400 \mu$ from the surface. The majority of recordings were taken about a depth of $600 \mu$. Often several units were recorded in succession in a single electrode penetration. Stimulation of the olfactory naris were always made on the same side as the recording. The opposite naris was covered with a moist tissue paper.

We recorded from 107 single cells in the char olfactory bulb. Most cells had an ongoing discharge characteristic for the unit $(0 \cdot 1-10 \mathrm{impulses} / \mathrm{sec})$. The overall rate and pattern of this tonic discharge seemed to be relatively stable over the time of 


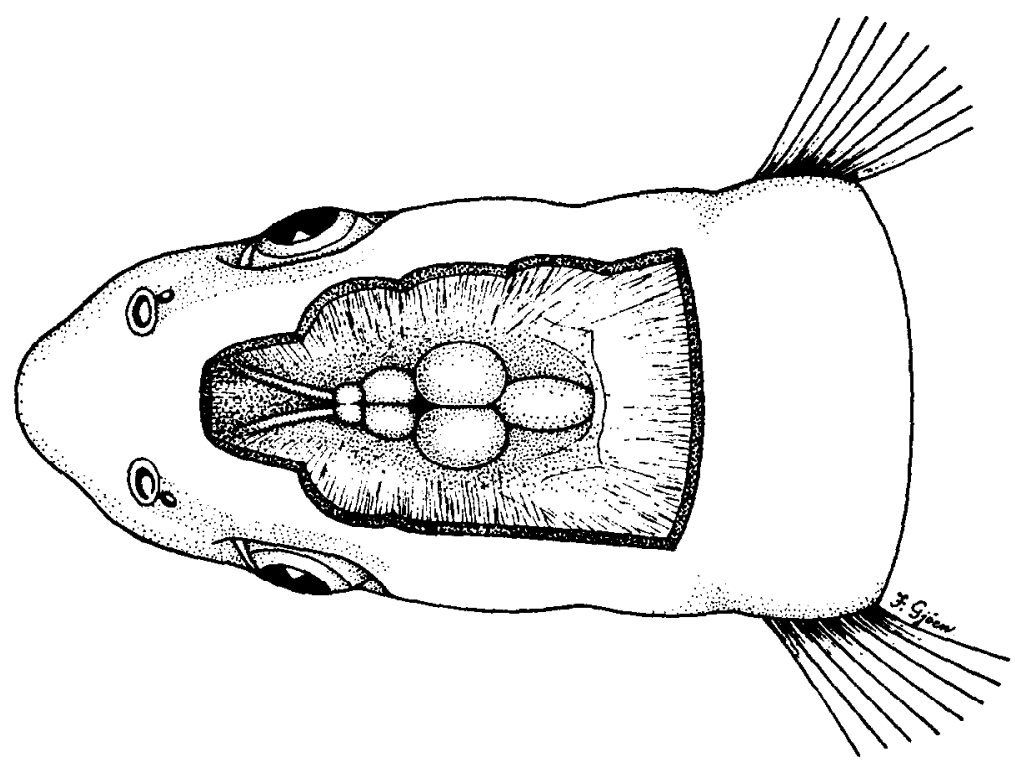

FIG. 2. Dorsal view of the head of a char showing the cut-away view of the brain. The position of the olfactory bulbs is demonstrated in relation to the telencephalon, optic lobes and the cerebellum.

observation of a particular unit. Initiating or terminating the flow of the rinse solution had little effect upon activity. Ninety-three ( 87 per cent) of the cells were affected by fish tank waters. That is, either activity was increased (excitation) or the ongoing discharge was suppressed (inhibition) during stimulation. The results suggest that the char olfactory receptors are sensitively tuned to biologically meaningful odours. In earlier observations on burbot and carp (Døving, 1966a; Nanba $e t a l$., 1966), stimulation with off-the-shelf odorants gave lower proportions of responsive olfactory bulb neurons than tank waters with char in the present experiments. Units with little or no activity during exposure to rinse water were generally not affected by fish odours.

In a detailed analysis 45 cells were tested, typically at least twice, with tank water from each of the 6 fish groups. The matrix of response patterns elicited by the initial presentations is shown in Table 1. In the total of $270(6 \times 45)$ possible responses, excitation occurred in 48 per cent, inhibition in 43 per cent and no response in 9 per cent of the cases. It can be seen from inspection of the rows that most cells ( 87 per cent) gave differential responses, i.e. some of the 6 stimuli excited and some inhibited a given cell. One unit (28-05) was inhibited by all 6 stimuli, and 5 units were either excited and unaffected $(+, 0)$ or inhibited and unaffected $(-, 0)$.

An example of the differential discharge to the various tank waters is shown in Fig. 3. The waters of young Vangsvatn, Løna and the Salangen migratory char 


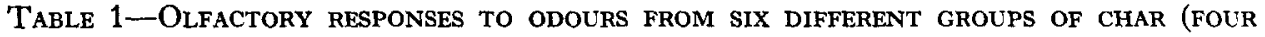
POPULATIONS)

\begin{tabular}{|c|c|c|c|c|c|c|}
\hline \multirow[b]{3}{*}{ Unit } & \multicolumn{6}{|c|}{ Odour sources } \\
\hline & A & B & $\mathrm{C}$ & $\mathrm{D}$ & E & $\mathrm{F}$ \\
\hline & $\begin{array}{c}\text { Young } \\
\text { Vangsvatn }\end{array}$ & $\begin{array}{c}\text { Adult } \\
\text { Vangsvatn }\end{array}$ & $\begin{array}{l}\text { Young } \\
\text { Løna }\end{array}$ & $\begin{array}{l}\text { Adult } \\
\text { Lona }\end{array}$ & $\begin{array}{c}\text { Young } \\
\text { Salangen } \\
\text { migratory } \\
\text { char }\end{array}$ & $\begin{array}{c}\text { Young } \\
\text { Salangen } \\
\text { stationary } \\
\text { char }\end{array}$ \\
\hline $26-01$ & + & + & + & - & + & + \\
\hline $26-05$ & - & - & - & - & 0 & 0 \\
\hline $26-06$ & + & - & + & + & + & + \\
\hline $26-07$ & - & + & + & + & + & - \\
\hline $28.01 *$ & - & + & + & - & + & + \\
\hline $28-02 *$ & - & + & + & - & + & + \\
\hline $28-03$ & + & - & + & + & - & - \\
\hline $28-05$ & - & - & - & - & - & - \\
\hline $28-06$ & + & - & - & + & - & $t$ \\
\hline $28-07 *$ & - & - & - & - & - & + \\
\hline $28-08 *$ & - & + & 0 & - & - & + \\
\hline $28-09 \dagger$ & + & + & + & - & + & - \\
\hline $28-10 \dagger$ & + & - & + & + & + & + \\
\hline $29-02 *$ & - & + & + & - & + & + \\
\hline $29-03 *$ & + & + & + & + & + & - \\
\hline $29-04 t$ & - & + & - & - & - & - \\
\hline $29-05 t$ & - & + & - & - & - & - \\
\hline $29-06$ & - & + & - & - & - & - \\
\hline $29-07$ * & + & - & + & - & + & - \\
\hline 29-08* & + & - & + & 0 & + & - \\
\hline $29-09$ & - & - & + & - & + & - \\
\hline 2910 & & & 1 & 0 & + & - \\
\hline $31-01$ & + & + & + & + & - & 0 \\
\hline $31-02$ & + & - & 0 & - & - & 0 \\
\hline $31-04$ & 0 & + & 0 & + & + & + \\
\hline $31-05$ & - & + & + & - & - & + \\
\hline $31-06$ & + & + & + & - & + & - \\
\hline $03-06$ & + & 0 & + & + & + & + \\
\hline $03-07$ & 0 & 0 & + & 0 & + & 0 \\
\hline $03-08$ & + & 0 & + & 0 & + & 0 \\
\hline $04-02$ & - & + & - & - & - & - \\
\hline $04-03$ & + & - & + & + & - & - \\
\hline $04-04$ & + & - & - & - & - & - \\
\hline $04-05$ & - & + & + & 0 & - & 0 \\
\hline 04-07 & + & - & - & 0 & + & - \\
\hline $04-08$ & + & - & + & - & + & + \\
\hline 04-09 & + & - & + & - & + & + \\
\hline $04-10$ & - & - & + & - & + & - \\
\hline 04-11 & + & - & - & + & + & - \\
\hline $04-12$ & + & 0 & + & - & + & - \\
\hline
\end{tabular}


TABLE 1 (cont.)

\begin{tabular}{|c|c|c|c|c|c|c|}
\hline \multirow[b]{3}{*}{ Unit } & \multicolumn{6}{|c|}{ Odour sources } \\
\hline & A & $\mathrm{B}$ & C & $\mathrm{D}$ & E & $\mathbf{F}$ \\
\hline & $\begin{array}{c}\text { Young } \\
\text { Vangsvatn }\end{array}$ & $\begin{array}{c}\text { Adult } \\
\text { Vangsvatn }\end{array}$ & $\begin{array}{l}\text { Young } \\
\text { Lona }\end{array}$ & $\begin{array}{l}\text { Adult } \\
\text { Lona }\end{array}$ & $\begin{array}{l}\text { Young } \\
\text { Salangen } \\
\text { migratory } \\
\text { char }\end{array}$ & $\begin{array}{c}\text { Young } \\
\text { Salangen } \\
\text { stationary } \\
\text { char }\end{array}$ \\
\hline 04-13 & 0 & + & + & - & + & + \\
\hline $05-01$ & + & - & + & $t$ & + & 0 \\
\hline $05-02$ & - & + & + & - & + & - \\
\hline $05-03$ & - & + & + & - & + & - \\
\hline $05-08$ & - & - & + & - & + & + \\
\hline \multicolumn{2}{|c|}{$\begin{array}{l}(48 \%) 130+(49) 22 \\
(43 \%) 116-(44 \cdot 5) 20\end{array}$} & $\begin{array}{l}(44 \cdot 5) 20 \\
(46 \cdot 5) 21\end{array}$ & $\begin{array}{l}(69) 31 \\
(24 \cdot 5) 11\end{array}$ & $\begin{array}{l}\text { (27) } 12 \\
(60) 27\end{array}$ & $\begin{array}{l}(64.5) 29 \\
(33.5) 15\end{array}$ & $\begin{array}{l}(35 \cdot 5) 16 \\
(49) 22\end{array}$ \\
\hline
\end{tabular}

Neurons 26-01 thru 31-06 were recorded from adult Vangsvatn char; neurons 04-02 thru 05-08 from Salangen char. Successive pairs of units marked * or $\dagger$ were recorded simultaneously. + , Excitation, - , inhibition; 0 , no effect.

excited the big unit, while waters of adult Vangsvatn, adult Lona and young Salangen stationary char all inhibited its activity. The response patterns elicited in the other smaller and simultaneously recorded unit were less conspicuous but similar, except in one case, viz. adult Løna whose water seemed not to affect this particular unit. Some units were selective in the sense that their responses were uniform except for one stimulus. For example, unit (26-01) was excited by all waters except adult Løna, which inhibited its activity. Units 29-04 and 29-05 were excited by the adult Vangsvatn and inhibited by the rest. As seen from Table 1 very few units were similarly affected by the six stimuli. These diverse combinations of response patterns suggested that the char populations release different odours. More rigorously a Cochran $Q$ test of Table 1 appropriate for repeated measures (six stimuli per neuron) led to the rejection of the hypothesis that these response patterns resulted from six repeated presentations of the same odour $(P<0.01$, $Q=20.2, N=45$ ]. [The statistical analysis gives a $P<0 \cdot 01$ whether one deletes the units with one or more " 0 " responses $(N=30)$ or randomly assigns + or - to the zero responses $(N=45)$.] Thus, even when the response analysis is restricted to a dichotomous classification ( + and - ), there is sufficient information for physiological discrimination by the olfactory cells of the odorants from various fish populations.

It is possible to examine the effects of particular stimuli more closely. For each of the fifteen possible pairs of stimuli (combinations of six stimuli like $A-B, A-C$, A-D, etc. of Table 1) we determined the percentage of single unit responses (units with one or more 0 entries were deleted) that were the same $(++$ or -- ) or different $(+-$ or -+$)$ as shown in Table 2 . In a typical pair of stimuli nearly 
Table 2-Percentage of olfactory bulb neurons with opposite $(+,-$ or,-+$)$ RESPONSES TO PAIRS OF CHAR ODOURS

\begin{tabular}{|c|c|c|c|c|c|}
\hline & $\begin{array}{c}\text { Adult } \\
\text { Vangsvatn }\end{array}$ & $\begin{array}{l}\text { Young } \\
\text { Lona }\end{array}$ & $\begin{array}{l}\text { Adult } \\
\text { Løna }\end{array}$ & $\begin{array}{c}\text { Salangen } \\
\text { sea char }\end{array}$ & $\begin{array}{c}\text { Salangen } \\
\text { stationary char }\end{array}$ \\
\hline Young & & & & & \\
\hline $\begin{array}{l}\text { Vangsvatn } \\
\text { Adult }\end{array}$ & 69 & 40 & 27 & 39 & $48 \cdot 5$ \\
\hline $\begin{array}{l}\text { Vangsvatn } \\
\text { Young }\end{array}$ & & $44 \cdot 8$ & 58 & $52 \cdot 5$ & 47 \\
\hline $\begin{array}{l}\text { Løna } \\
\text { Adult }\end{array}$ & & & 53 & 16 & $44 \cdot 5$ \\
\hline $\begin{array}{l}\text { Lona } \\
\text { Salangen }\end{array}$ & & & & $52 \cdot 5$ & $45 \cdot 8$ \\
\hline Sea char & & & & & $47 \cdot 4$ \\
\hline
\end{tabular}

Matrix of the fifteen possible pairs of odours from the six groups of char.

Data from analysis of Table $1 . N, 30$.

half the neurons showed opposite responses ( $M=45.6$ per cent; $M d n=47.2$ per cent). Young Vangsvatn and adult Løna tended to have opposite (69 per cent) effects; whereas young Løna and young migratory char tended to have the same (16 per cent opposite; 84 per cent the same) effects upon the neuron. It is important to stress that even a small percentage of units with differential responses may have behavioral significance, because these patterns of excitation and inhibition were highly reliable. Most of the entries in Table 1 were replicated by giving at least two presentations of the stimuli. Since only 5 of 151 entries changed with replication $(P<0.0001$ of random fluctuation; normal approximation to the binomial distribution, $P=Q=0.5$ ), it can be concluded that the difference between pairs of stimuli are reliable reflections of differences in the properties of the odorants. It is a pertinent comparison that the odours from young migratory and young stationary char elicited differential responses in 47.4 per cent of the single units.

The present results suggest that these groups of char release different odours and that a substantial portion of the olfactory bulb cells are differentially tuned to mediate physiological and presumably behavioral discrimination among these naturally occurring fish odours.

To determine whether olfactory discrimination was sufficiently precise to differentiate between two individuals of the same population, two new plastic tanks (1201.) were arranged with identical water flow rates $(61 . / \mathrm{min})$. There was no detectable difference in the olfactory cell response to the two tank waters without fish. Within 25 min of the introduction of one adult male Vangsvatn char into each tank (same age and length) these tank waters evoked reactions in the olfactory neurons. In some cases (four of seventeen cells) the effects were differential. An example of a unit being excited by the A, but inhibited by the B Vangsvatn char is shown in Fig. 4. 
A

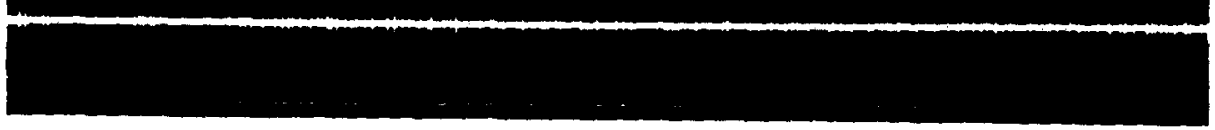

B
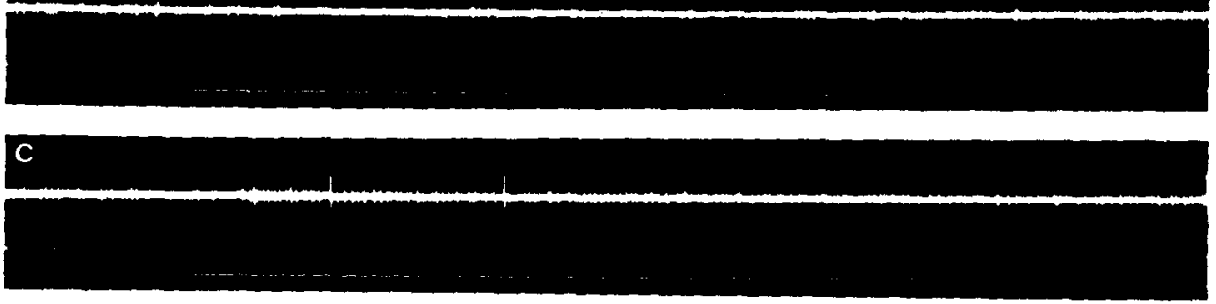

D

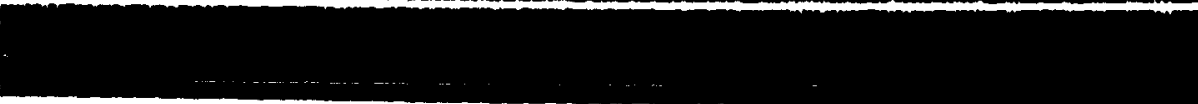

$\mathbf{E}$

Frg. 3. Recordings of the activity of two bulbar units (29-07, big spike and 29-08, small spike) recorded at a depth of $381 \mu$ from the surface. The middle line in each record monitors the heart beat, the time interval of which is $1 \mathrm{sec}$. Stimulations are indicated by the lowest trace. Water from a tank without fish was used as a rinse before and after each stimulus. Tank waters from the following char populations were used: $\mathrm{A}$, young Vangsvatn; $\mathrm{B}$, adult Vangsvatn; $\mathrm{C}$, young Lona; $D$, adult Lona; $E$, young Salangen migratory char; $F$, young Salangen stationary char.

In a previous study (Døving et al., 1973) it was found that the skin mucous was a very potent olfactory stimulus. We made efforts to investigate the effectiveness of the slime in eliciting differential responses from the olfactory neurons. Representative fish from the six groups were individually placed in a bath (i.e. 0.51 , tank water in a small plastic tray) for $5 \mathrm{~min}$. Immediately thereafter each fish was quickly killed and the slime collected. Care was taken to avoid contaminations from blood, the urogenital opening or from the hands in preparing the fish. In a series of recordings we observed the effect on twenty-three units of stimulation by the fish 


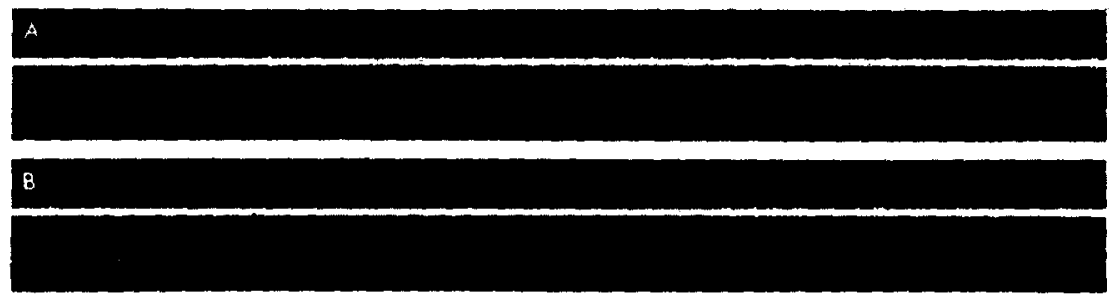

Frg. 4. Recording of impulse activity of a single cell (29-10) with stimulation by odours from two male char, A and B (see text). The EKG is shown in the middle line; time interval between heart beats $1 \mathrm{sec}$. Stimulations are indicated by white traces at bottom.

bath water and the slime water (diluted 1 part in 100 parts tank water). Eighty-five per cent of the tests with slimes caused a change in unit activity. Comparisons of the effects elicited by slime water and bath water demonstrated that in 80 per cent of the cases the responses were similar $(33++$ and $48--)$. Opposite effects were elicited in 20 per cent of the cases (twelve, slime + and bath - ; and nine slime and bath +$)$. Chi-square analysis of a $2 \times 2$ contingency table $(++,+-,-+$, - -) of these responses indicated that such a distribution is most unlikely to occur by chance $(P<0.001)$. This suggests that the odorants in the slime are substantially the same as those in the bath. The generous secretion of slime by these fish further suggests that slime is the quantitatively important source of the odorants given off in the waters by the char. This does not exclude the possibility of specialized secretions released by other means under particular conditions (e.g. alarm substances).

\section{DISCUSSION}

In the following discussion we will relate the results of our present experiments with earlier work on the electrophysiology of the olfactory sense in fish. Further, we will discuss our findings on single unit activity in relation to the presence of pheromones in fish and their pertinence to discriminatory behavior and migration in anadromous fish.

In order to determine the functional significance of differentially responding cells it is first necessary to establish that the differential responses are reliable and not a result of chance fluctuation. The excitatory or inhibitory character of a response in our experiments was highly reliable, e.g. if a stimulus inhibited on the first trial it inhibited on subsequent trials. Thus, even a small percentage of cells responding differentially to a pair of odorants would be physiologically significant.

It is likely that the concentrations of tank chemicals were initially low inasmuch as the tank water was rapidly turning over. Furthermore, dilution of the tank water only reduced the vigor of the response. This agrees with single unit recording in the frog olfactory bulb where only a few units display excitation at low and inhibition at higher odorant concentrations (Døving, 1964). Consequently, it is 
improbable that the differential olfactory responses to char populations resulted merely from different dilutions of the same odorants in the fish tanks. Instead there must be qualitative differences in the patterns of odours released by these char populations. The large percentage of cells with differential responses further suggests that there is ample physiological substrate to mediate behavioral discriminations. Finally, evidence for the relevance of such an analysis of patterns of excitation and inhibition to behavioral discrimination is available in comparisons of frog differential olfactory responses and psychophysical data from human subjects (Døving, 1966b; Døving \& Lange, 1966).

Mucous was shown by Wrede (1932) to contain the active principle for the olfactory discriminatory behavior of minnows, and Todd et al. (1967) believed that mucous contained a pheromone important in bullhead behavior. It has been suggested that mucous also contains the pheromone necessary to attract char back to the spawning site (Nordeng, 1971). Recent studies showed that mucous was an effective olfactory stimulant (Døving et al., 1973). The present results suggest that the mucous is responsible for much of the odour released by the char in tank water.

Electrophysiological studies of fish olfaction related to the natural biology of the fish have used the summated EEG response (Hara et al., 1965). In the series of experiments on EEG activation of the olfactory bulb the home water always gave a large response. This is also understandable since the home waters were associated with salmon ponds and hatcheries with their extensive aggregation of fish (e.g. Fig. 4, Ueda et al., 1967). It has also been assumed that the olfactory EEG arousal to home water is a direct electrophysiological manifestation of olfactory memory underlying homing (Oshima et al., 1969a, c, pp. 2131-2132). In order to prove that the EEG arousal or any other sensory response is learned it would be necessary to show a change in responsiveness to waters as a result of experience. What has been shown in a series of tests is that leaving fish in various waters will increase the effectiveness of each type of water as a stimulatory agent (Oshima et al., 1969b, Tables 2 and 3). In view of the present results the most reasonable interpretation is that the stimulus properties of the water had changed as a result of chemicals secreted by the fish; not that the responsiveness of the fish olfactory system had changed, i.e. EEG arousal was not a learned response.

Our results suggest that the char olfactory receptors are sensitively tuned to biologically meaningful odours and that the olfactory system in char is capable of detecting and discriminating among various char odours. This means that the migratory populations of char during upstream runs have the potential ability to orient along odour tracks released from specific populations of standing young relatives in the nursery areas of their parent river system.

\section{SUMMARY}

1. Single unit activity was recorded in the olfactory bulb of the anesthetized char (Salmo alpinus L.). 
2. Ninety-three of 107 bulbar cells responded to fish odours from four distinct char populations. Thirty-nine of the 45 responsive cells studied in detail gave differential responses, as defined by excitation to some and inhibition to other char odours. The pattern of excitation and inhibition was a highly reliable property of each unit. Two populations (migratory and stationary char from Salangen) mix in the same watershed, yet have different spawning grounds. Their odours elicited differential responses in $\mathbf{4 7 . 4}$ per cent of the responsive single units.

3. Preliminary evidence was also put forward for discrimination of odours of individual fish by olfactory bulb neurons.

4. Diluted mucous from the body surface and odorants released by the same char into water have closely similar stimulatory effects. Mucous may well contain the principal source of odorants released by the char.

5. The proposition that fish odours may act as pheromones which assist in type recognitions and in near-migration to homestream spawning sites is discussed. We have shown that there appears to be adequate physiological substrate for the mediation of these olfactory discriminations.

\section{REFERENCES}

Clemens W. A., Foerster R. E. \& Pitchard A. 1. (1939) The migration of Pacific salmon in British Columbia water. Am. Assoc. Advance Sci. 8, 51-59.

Døving K. B. (1964) Studies of the relation between the frog's electro-olfactogram (EOG) and single unit activity in the olfactory bulb. Acta physiol. scand. 60, 150-163.

Døving K. B. (1966a) The influence of olfactory stimuli upon the activity of secondary neurones in the burbot. Acta physiol. scand. 66, 290-299.

Døving K. B. (1966b) Analysis of odour similarities from electrophysiological data. Acta physiol. scand. 68, 404-418.

Døving K. B., Enger P. S. \& Nordeng H. (1973) Electrophysiological studies on the olfactory sense in char (Salmo alpinus L.). Comp. Biochem. Physiol. 45A, 21-24.

Døving K. B. \& LANGe A. L. (1967) Comparative studies of sensory relatedness of odours. Scand. Y. Psychol. 8, 47-51.

voN FrISCH K. (1941) Über einen Schreckstoff der Fischhaut und seine biologische Bedeutung. Z. vergl. Physiol. 29, 46-145.

Göz H. (1941) Über den Art- und Individualgeruch bei Fischen. Z. vergl. Physiol. 20, 1-45.

Groves A. B., Collins G. B. \& Trefethen P. S. (1968) Roles of olfaction and vision in choice of spawning site by homing adult chinook salmon (Oncorynchus tshawytscha). 7. Fish. Res. Bd Can. 25, 867-876.

Hara T. J., UEDa K. \& GoRBman A. (1965) Electroencephalographic studies of homing salmon. Science, Wash. 149, 884-885.

Harden Jones F. R. (1968) Fish Migration. Edward Arnold, London.

Hasler A. D. (1960) Homing orientation in migrating fishes. Ergebn. Biol. 23, 94-115.

Hasler A. D. (1970) Chemical ecology of fish. In Chemical Ecology, pp. 219-234. Academic Press, New York.

Nanba R., Djahanparwar B. \& Baumgarten R. V. (1966) Erregungsmuster einzelner Fasern des Tractus olfactorious lateralis des Fisches bei Reizung mit verschiedenen Geruchstoffen. Pflügers Arch. ges. Physiol. 288, 134-150.

Nordeng H. (1961) On the biology of char (Salmo alpinus L.) in Salangen, North NorwayI. Age and spawning frequency determined from scales and otoliths. Nytt Mag. Zool. 10, 67-123. 
NoRDENG H. (1971) Is the local orientation of anadromous fishes determined by pheromones? Nature, Lond. 233, 411-413.

Oshima K., Hahn W. E. \& GoRbman A. (1969a) Memory blocking agents: effects on olfactory discrimination in homing salmon. Science, Wash. 165, 86-88.

Oshima K., HAHN W. E. \& GORBMAN A. (1969b) Olfactory discrimination of natural waters by salmon. F. Fish. Res. Bd Can. 26, 2111-2121.

Oshima K., HaHN W. E. \& Gorbman A. (1969c) Electroencephalographic olfactory responses in adult salmon to waters traversed in the homing migration. F. Fish. Res. Bd Can. 26, 2123-2133.

Pfeiffer W. (1962) The fright reaction of fish. Biol. Rev. 37, 495-511.

Stasko A. B. (1971) Review of field studies on fish orientation. Ann. N.Y. Acad. Sci. 188, $12-29$.

Todd J. H., Atema J. \& BARDACH J. E. (1967) Chemical communication in social behavior of a fish, the yellow bullhead (Ictalurus natalis). Science, Wash. 158, 672-673.

UEDA K., HARA I. J. \& GoRBMAN A. (1967) Electroencephalographic studies on olfactory discrimination in adult spawning salmon. Comp. Biochem. Physiol. 21, 133-144.

WiSBY W. J. \& HASLER A. D. (1954) Effect of olfactory occlusion on migrating silver salmon (O. kisutch). F. Fish. Res. Bd Can. 11, 472-478.

Wrede W. L. (1932) Versuche über den Artduft der Ellritze. Z. vergl. Physiol. 17, 510-519.

Key Word Index-Char; fish migration; salmon homing; olfactory bulb; fish odours, Salmo alpinus; pheromones; olfactory neurons; olfactory discrimination; smell; skin mucous; sensory responses. 